\title{
FRANS ANNEESSENS EN DE BRUSSELSE OPSTAND VAN 1717-1718
} Klaas Van Gelder

Musées et Archives de la Ville de Bruxelles | « Cahiers Bruxellois - Brusselse Cahiers »

2018/1 L | pages 143 à 173

ISSN 1784-5157

ISBN 9782874880193

Article disponible en ligne à l'adresse :

https://www.cairn.info/revue-cahiers-bruxellois-2018-1-page-143.htm

Distribution électronique Cairn.info pour Musées et Archives de la Ville de Bruxelles.

(C) Musées et Archives de la Ville de Bruxelles. Tous droits réservés pour tous pays.

La reproduction ou représentation de cet article, notamment par photocopie, n'est autorisée que dans les limites des conditions générales d'utilisation du site ou, le cas échéant, des conditions générales de la licence souscrite par votre établissement. Toute autre reproduction ou représentation, en tout ou partie, sous quelque forme et de quelque manière que ce soit, est interdite sauf accord préalable et écrit de l'éditeur, en dehors des cas prévus par la législation en vigueur en France. Il est précisé que son stockage dans une base de données est également interdit. 


\title{
FRANS ANNEESSENS EN DE BRUSSELSE OPSTAND VAN 1717-1718
}

\author{
KLAAS VAN GELDER
}

In oktober 2017 woedde in Brussel een kleine polemiek waarin Frans Anneessens, bijna drie eeuwen na zijn onthoofding, een hoofdrol speelde. De Brusselse minister van mobiliteit, Pascal Smet, stelde voor om de naam van premetrostation Anneessens, naast het gelijknamige plein, te herdopen in 'Toots Thielemans', de jazzlegende uit de nabijgelegen Marollen. Brussels gemeenteraadslid Zoubida Jellab reageerde prompt op Facebook: "C'est François Anneessens qu'on redécapite". ${ }^{1}$ Enkele dagen later verklaarde Smet om meerdere redenen van de naamswijziging af te zien. Ter compensatie zal een nieuw te bouwen metrostation naar Thielemans worden vernoemd. ${ }^{2}$

Niet alleen praktische bezwaren speelden in de ministeriële bocht een rol. De naam 'Anneessens' wordt vandaag wellicht meer met het plein, de premetrohalte en de omliggende wijk geassocieerd dan met de historische figuur. Toch toont Jellabs Facebookreactie dat de aanvoerder van de laatste grote Brusselse opstand tegen het centrale gezag nog steeds sympathie opwekt. In de negentiende en begin twintigste eeuw was zijn heldenstatus veel groter. Dat hing samen met de noden van de jonge Belgische staat die zijn bestaansrecht met een glorieuze voorgeschiedenis en roemrijke voorvaderen trachtte te legitimeren. De mythologisering van Anneessens en de demonisering

1. Facebookpost van Zoubida Jellab, 21 oktober 2017 (https://www.facebook.com, geraadpleegd op 31 mei 2018).

2. Zie hiervoor de volgende krantenartikelen: "Protest tegen metrostation Toots Thielemans" en "Toots Thielemans krijgt ander metrostation" in De Standaard, 23 en 26 oktober 2017 (www.standaard.be, geraadpleegd op 28 mei 2018); "Protest tegen metrostation Toots" en "Metrostation Anneessens verandert toch niet in 'Toots Thielemans" in BRUZZ, 23 en 26 oktober 2017 (www.bruzz.be, geraadpleegd op 28 mei 2018). 
van diens antagonist, markies van Prié, weken niet zelden sterk af van de historische werkelijkheid. In deze bijdrage keer ik daarom terug naar eigentijds bronnenmateriaal. De tekst bestaat uit twee delen. Eerst komt de opstand zelf aan bod, met de oorzaken, de voornaamste actoren en het verloop ervan. In deel twee concentreer ik mij op de repressie en de rol van Anneessens in de opstand. Daarvoor baseer ik mij voornamelijk op het gerechtelijk onderzoek door de Raad van Brabant dat tot zijn terdoodveroordeling leidde. Beide delen van het corpus maken duidelijk dat de revolte in 1717-1718 en de beteugeling ervan in veel opzichten traditionele patronen volgden. Wel uniek was de uitvergroting van deze specifieke opstand in de Belgische geschiedschrijving. In het besluit reflecteer ik daarom kort op Anneessens' heldendom in de jaren, decennia en eeuwen na zijn dood.

\section{Over belastingen en privilegies: de Brusselse opstand van $1717-1718$}

Stedelijke opstanden waren in de middeleeuwse en vroegmoderne Lage Landen niet uitzonderlijk. In deze sterk verstedelijkte regio bestond er sinds de twaalfde eeuw een heuse cultuur van opstandigheid. Die was nauw verbonden met de grote autonomie en financiële slagkracht van veel steden. ${ }^{3}$ Elke stad had een eigen bestuurs- en

3. Stedelijke opstanden hebben veel pennen in beweging gebracht. Hier volstaat een kleine greep uit het grote aanbod. Voor langetermijnoverzichten met aandacht voor structurele kenmerken van de opstandigheid in de Lage Landen: DUMOLYN J., HAEMERS J., Patterns of Urban Rebellion in Medieval Flanders, in Journal of Medieval History, vol. 31, 2005, p. 369-393; VAN HONACKER K., Lokaal verzet en oproer in de 17de en 18de eeuw. Collectieve acties tegen het centraal gezag in Brussel, Antwerpen en Leuven, Kortrijk-Heule, 1994; DEKKER R., Holland in beroering. Oproeren in

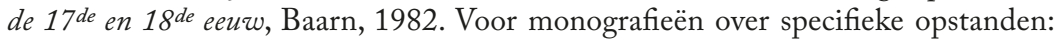
DUMOLYN J., De Brugse opstand van 1436-1438, Kortrijk-Heule, 1997; HAEMERS J., De Gentse opstand, 1449-1453. De strijd van rivaliserende netwerken om het stedelijke kapitaal, Kortrijk-Heule, 2004. In navolging van Jan Dumolyn in zijn boek over de Brugse opstand (p.15) hanteer ik de begrippen 'opstand' en 'revolte' om te verwijzen naar een langere contestatie van gezag. 'Oproer' refereert aan kortere acties, veelal met een heftiger, gewelddadiger karakter. Een opstand kan verschillende momenten van oproer omvatten. 
rechtssysteem dat ondanks regionale variaties in grote delen van Europa dezelfde kenmerken vertoonde. De stadsbewoners die het officiële stadsburgerschap genoten en in de Lage Landen 'burgers' of 'poorters' werden genoemd, konden bijvoorbeeld enkel voor een stedelijke rechtbank en door stadsgenoten worden berecht. Doorheen de eeuwen werd deze stedelijke autonomie geleidelijk ingeperkt ten gunste van het vorstelijke machtsapparaat. Zo kon vanaf de Late Middeleeuwen in vorstelijke gerechtshoven beroep worden aangetekend tegen vonnissen van stedelijke rechtbanken. Ook werden stedelingen steeds vaker door de landsheer belast, al dan niet met hun voorafgaande goedkeuring. Het spreekt voor zich dat deze ontwikkelingen met de nodige spanningen gepaard gingen, die tot protesten aanleiding konden geven. ${ }^{4}$

Historici onderscheiden in de veelheid van stedelijke opstanden in de Nederlanden twee grote patronen. Enerzijds namen de stedelingen de wapens op tegen de landsheer of -vrouw en tegen het vorstelijke machtsapparaat als zij de stedelijke belangen aangetast of bedreigd achtten. Dit wordt de 'grote traditie' van stedelijke opstandigheid genoemd. Tegelijk bestond er een tweede patroon, de zogenoemde 'kleine traditie', namelijk revoltes tegen de veelal oligarchische stadsbestuurders. Dit begon doorgaans met de eis om verantwoording af te leggen over het (wan)bestuur van de stad. Beide tradities waren niet geïsoleerd. Integendeel, ze traden gelijktijdig op en versterkten elkaar. $^{5}$

4. Een heldere synthese over vroegmoderne stedelijke politiek in Europa levert FRIEDRICHS Ch.R., Urban Politics in Early Modern Europe, Londen, New York, 2000.

5. BLOCKMANS W.P., Alternatives to Monarchical Centralisation: The Great Tradition of Revolt in Flanders and Brabant, in KOENIGSBERGER H.G. (red.), Republiken und Republikanismus im Europa der Frühen Neuzeit, München, 1988, p. 145154; BOONE M., PRAK M., Vorsten, patriciërs en burgers: de kleine en grote traditie van stedelijke revoltes in de Lage Landen, in DAVIDS K., LUCASSEN J. (red.), Een wonder weerspiegeld. De Nederlandse Republiek in Europees perspectief, Amsterdam, 2005, p. 91-124. 
De oorzaken van stedelijk verzet laten zich onder enkele algemene noemers samenvatten. ${ }^{6}$ Veelvoorkomend waren acties naar aanleiding van (vermeende) inbreuken op de stedelijke autonomie en de voorrechten van bepaalde belangengroepen binnen het stedelijke weefsel. Daar nauw mee verbonden was de problematiek van de fiscaliteit, zeker indien het om vorstelijke taxatie ging. Vooral indirecte belastingen die het armere deel van de bevolking disproportioneel troffen, konden een explosieve uitwerking hebben. Het stationneren van een vorstelijk garnizoen binnen de stadsmuren was eveneens een delicaat gegeven. Hoewel recent werd aangetoond dat de betrekkingen tussen een garnizoen en de burgerbevolking niet per definitie slecht waren en een garnizoen de stad ook economisch voordeel kon brengen ${ }^{7}$, leidden confrontaties tussen soldaten en burgers geregeld tot opstootjes. Een vierde oorzakencluster is de 'moral economy', waarmee het geheel van geschreven en ongeschreven waarden en normen wordt aangeduid die het voortbestaan van een gemeenschap überhaupt mogelijk maken. ${ }^{8}$ Voldoende voedsel voorzien tegen redelijke prijzen behoorde in die optiek tot de kerntaak van de stadsbestuurders.

Stedelijke opstanden waren zelden spontane opwellingen van gratuit en willekeurig geweld. Integendeel, zij vertoonden een zekere planmatigheid. De aanvoerders probeerden aan hun acties een legitiem karakter te geven, onder andere door gevestigde politieke organen voor hun kar te spannen. Doelen werden daarbij weloverwogen uitgekozen. Zo was het niet ongebruikelijk dat in tijden van voedselschaarste de overvolle schuren en pakhuizen van op prijsstijging speculerende

6. Het volgende overzicht is gebaseerd op VAN HONACKER K., lokaal verzet en oproer... op.cit., passim, maar deze vier categorieën overlappen grotendeels met wat Christopher Friedrichs samenvat onder de noemers economische kwesties, ansprakelijkheid van de wethouders en stedelijke autonomie: FRIEDRICHS Ch.R., Urban Politics... op.cit., p. 25-34. Friedrichs voegt daar religie aan toe, al bleef deze categorie in de Oostenrijkse Nederlanden beperkt.

7. Zie bijvoorbeeld VERMEESCH G., War and garrison towns in the Dutch Republic: the cases of Gorinchem and Doesburg (c. 1570 - c. 1660) in Urban History, vol. 36, 1, 2010, p. 3-23.

8. Zie ook THOMPSON E.P., The Moral Economy of the English Crowd in the Eighteenth Century in Past E Present, vol. 50, 1971, p. 76-136. 
boeren en kooplieden werden geviseerd. De activisten verdeelden het graan vervolgens gratis of aan redelijk geachte prijzen. Ook hadden deelnemers aan een oproer het vaak specifiek gemunt op de huizen en bezittingen van functionarissen die met het wanbeleid of met impopulaire maatregelen vereenzelvigd werden. In elk geval was geweld veelal de ultieme stap in een lang onderhandelingsproces. Aan de escalatie gingen niet zelden een reeks verzoeningspogingen of uitnodigingen tot gesprek vooraf. Gebruikelijke technieken om het misnoegen aan te kaarten waren het indienen van petities - een algemeen aanvaard drukkingsmiddel in vroegmodern Europa -, het aanstellen van een delegatie die met de hogere instantie (het stadsbestuur of de landsheer) moest gaan onderhandelen, of de weigering bepaalde belastingen te betalen of goed te keuren. Ook toevlucht tot een bemiddelaar behoorde tot de mogelijkheden. Slechts als de vreedzame actiemiddelen uitgeput waren en zij niet tot genoegdoening hadden geleid, ging men over tot publieke demonstraties of tot geweld. ${ }^{9}$

Ook de Brusselse revolte waarin Frans Anneessens een hoofdrol zou spelen, beantwoordt aan deze logica. Deze opstand was bovendien een schakel in een lange ketting van verzet. De Negen Naties, die de dekens van 49 Brusselse ambachten groepeerden en naast de magistraat en de Wijde Raad het derde lid van het Brusselse stadsbestuur vormden, namen doorgaans het voortouw. Via dit orgaan hadden de dekens van de ambachten een stem in het toekennen of weigeren van belastingen (beden en subsidies) aan de vorst. ${ }^{10}$ In 1619 protesteerden zij zowel tegen de verspilling van belastingsgelden door de magistraat als tegen de pogingen van de regering om de vereiste maar steeds weer

9. FRIEDRICHS Ch.R., Urban Politics... op.cit., p. 35-49.

10. Het Brusselse stadsbestuur bestond uit drie leden: (1) de magistraat, schepenbank of wet die instond voor het dagelijkse bestuur, (2) de Wijde Raad, een doorgaans volgzaam adviserend orgaan dat vooral een rol speelde bij het consent met de vorstelijke belastingen, en (3) de Negen Naties, die aan hun instemming veel vaker voorwaarden koppelden. De instemming van deze drie leden was vereist voor het volledige consent met de beden en subsidies aan de vorst: VAN HONACKER K., Bestuursinstellingen van de stad Brussel (12de eeuw - 1795), in VAN UYTVEN R., BRUNEEL C., COPPENS H. en AUGUSTYN B. (red.), De gervestelijke en lokale overheidsinstellingen in Brabant en Mechelen tot 1795, vol. 2, Brussel, 2000, p. 413-426. 
uitgestelde instemming van de Naties met bepaalde heffingen te omzeilen. De kleine en grote traditie van opstandigheid haakten dus ineen. Het resultaat was echter een nederlaag voor de ambachten. Er kwam een nieuw reglement voor de stad Brussel dat het ledental van de achterraad van de Naties, een soort adviesorgaan, beperkte. Op die manier werd protest tegen het regeringsbeleid moeilijker gemaakt. Ook in 1680 en 1681 vormden de voorwaarden van de goed- of afkeuring van vorstelijke belastingen de rode draad doorheen de onrust in de ambachtsmiddens. Ook ditmaal vaardigde de overheid een nieuw reglement uit om meer greep te krijgen op het stadsbestuur. ${ }^{11}$

Een van de langstdurende revoltes deed zich voor helemaal op het eind van de zeventiende eeuw. In 1698 leidde de publicatie van de kort voordien teruggevonden privilegies van de Negen Naties tot onrust. Vele ervan bleken in vergetelheid te zijn geraakt. Anneessens was op dat ogenblik deken van de Sint-Christoffelnatie. Hij was een voorstander van het herstel van deze voorrechten maar speelde geen leidende rol in het verzet. ${ }^{12}$ De Naties zetten druk door niet in te stemmen met bede-aanvragen en door op het stadhuis te blijven zitten na door de magistraat te zijn ontbonden. Zo konden zij de Brusselaars mobiliseren en een draagvlak creëren voor hun eisen. Die behelsden fiscale grieven, economische verzuchtingen en politieke verlangens. Onder de groeiende druk gaf de regering op steeds meer punten toe tot landvoogd Maximiliaan Emmanuel van Beieren in december 1699 troepen naar de stad haalde. Tegelijk opende de Raad van Brabant een onderzoek tegen de voornaamste (en voortvluchtige) verdachten, waaronder verschillende gildedekens met een zitje in de Negen Naties. De straffen die werden uitgesproken waren zwaar, maar in december 1700 verkregen de veroordeelden - waartoe Anneessens voor alle duidelijk niet hoorde - gratie. Intussen waren de meeste toegevingen teruggeschroefd en op 12 augustus 1700 werd een aanvullend reglement voor de stad Brussel uitgevaardigd. Dat moest

11. VAN HONACKER K., lokaal verzet en oproer... op.cit., p. 97-111.

12. DELVA A., Annees(s)ens, Frans (Francis, Franciscus), Brussels ambachtsdeken, in Nationaal Biografisch Woordenboek [NBW], vol. 14, Brussel, 1994, kol.1-2. 
gecoördineerde verzetsacties extra bemoeilijken. De cruciale bepalingen betroffen de Wijde Raad en de Negen Naties. Hun ledental werd opnieuw fors ingeperkt (de achterraad kromp van 148 tot 49 leden). Ook werd de procedure voor het instemmen met de beden versoepeld. Voortaan was er sprake van een volledig Brussels consent als de twee eerste leden van het stadsbestuur en minstens vier Naties het licht op groen zetten, ofwel één van de eerste twee leden en minimaal vijf Naties. $^{13}$

De menselijke tol bleef dus beperkt maar de politieke gevolgen van de opstand in 1698-1699 waren groot. De spreekbuizen van de ambachtsmeesters werden hard aangepakt. De internationale politiek drong de kwestie van het aanvullend reglement echter naar de achtergrond. Eind 1700 overleed namelijk de kinderloze Karel II van Spanje. Met hem stierven de Spaanse Habsburgers uit. De onmetelijke Spaanse monarchie, waartoe ook de Zuidelijke Nederlanden behoorden, werd de inzet van de bloedige Spaanse Successieoorlog. Twee troonpretendenten streden om de Spaanse erfenis: de Franse prins Filips van Anjou (later koning Filips V van Spanje) en aartshertog Karel uit de tak der Oostenrijkse Habsburgers. Beide werden door een internationale coalitie gesteund. De strijd werd uiteindelijk beslecht aan de onderhandelingstafel met de vredesverdragen van Utrecht, Rastadt en Baden (1713-1714). De Spaanse territoriën werden onder de twee pretendenten verdeeld. Zo werden de vroegere Spaanse Nederlanden Oostenrijks. Aartshertog Karel, inmiddels keizer Karel VI, werd de nieuwe landsheer. Hij erfde echter uitgeputte regio's. Jarenlang was dit gebied één groot slagveld geweest. De gigantische legers en hun logistieke noden hadden zwaar op het land gewogen. Gedwongen contributies en plunderingen waren schering en inslag. ${ }^{14}$ Tegen die

13. VAN HONACKER K., lokaal verzet en oproer... op.cit., p. 113-123. Het blijft wachten op een grondige analyse van deze opstand. De tekst van het aanvullend reglement kan worden gevonden in WOUTERS J.M., Het sesde deel vande placcaerten ende ordonnantien vande Hertoghen van Brabandt, princen van dese Nederlanden, Brussel, 1738, p. 89-91.

14. De Spaanse Successieoorlog en zijn impact op de Zuidelijke Nederlanden komt aan bod in DE SCHRYVER R., Who had Sovereignty in the Southern Netherlands 
achtergrond hadden de Brusselaars andere zorgen aan hun hoofd dan de politieke strijd tegen het aanvullend reglement. Het ongenoegen bleef echter smeulen en van zodra de naoorlogse situatie stabiel was, stak het protest tegen het muilkorven van de ambachten opnieuw de kop op. ${ }^{15}$

Een eerste teken aan de wand waren de Antwerpse en Brusselse bedeweigeringen. Anders dan in het graafschap Vlaanderen was er in het hertogdom Brabant een unanimiteitsregel van kracht. De drie standen - clerus, adel en derde stand - moesten hun fiat geven, vooraleer de vorst belastingen kon laten innen. Bovendien gold die unanimiteit in principe ook binnen de derde stand, die in Brabant bestond uit de drie hoofdsteden Leuven, Brussel en Antwerpen. En binnen die hoofdsteden moesten ook de verschillende geledingen van het stadsbestuur hun akkoord verlenen. Bijgevolg kon de weigering van bijvoorbeeld de Negen Naties de hele Brabantse toekenningsprocedure doen stokken. Tussen 1714 en 1716 weigerden twee leden van het Antwerpse stadsbestuur hun instemming te verlenen met de bedeaanvraag. Pas toen de regering kortingen beloofde ter compensatie van de Antwerpse oorlogsleveringen en de geleden oorlogsschade, kwam

during the War of the Spanish Succession (1700-1715)? in ASAERT G., Recht en instellingen in de oude Nederlanden tijdens de Middeleeuwen en de Nieuwe Tijd. Liber Amicorum Jan Buntinx, Leuven, 1981, p. 483-497; DHONDT F., Op zoek naar glorie in Vlaanderen. De Zonnekoning en de Spaanse successie (1707-1708), Kortrijk-Heule, 2011; VAN GELDER K., Regime Change at a Distance. Austria and the Southern Netherlands Following the War of the Spanish Succession (1716-1725), Leuven, 2016, p. 88-111.

15. Over de Brusselse opstand die na de Spaanse Successieoorlog losbarstte bestaat veel literatuur. Toch is er nood aan een studie die de nieuwste wetenschappelijke inzichten over opstandigheid met een diepgaand bronnenonderzoek verbindt. De voornaamste werken zijn HENNE A., WAUTERS A., Histoire de la ville de Bruxelles. Nouvelle édition du texte original de 1845 augmentée de nombreuses reproductions de documents choisis par Mina Martens, archiviste de la ville, Brussel,1969, vol.2, p.172-213; BANNEUX P., Un épisode du gouvernement de Prié: le mouvement insurrectionnel à Bruxelles de 1717 à 1719, Brussel, niet-verdedigde en onuitgegeven doctoraatsverhandeling ULB, 1938; VAN HONACKER K., lokaal verzet en oproer... op.cit., p.123-131; DECUYPERE I., Les troubles à Bruxelles. De positie van gevolmachtigd minister Prié en de Raad van State in de oproer en het proces tegen de naties 1717-1719, Gent, onuitgegeven masterscriptie UGent, 2010; VAN GELDER K., Regime Change... op.cit., p. 213-235. 
er een akkoord. ${ }^{16}$ In 1715 en 1716 stelden ook de Brusselse Naties hun veto tegen bepaalde heffingen. In 1717 kregen zij de steun van de Wijde Raad. De ambachten betoogden dat zij net als Antwerpen een reductie verdienden. Per slot van rekening had Brussel zwaar onder de bombardementen van 1695 en 1708 geleden en was de handel door de oorlog stilgevallen. ${ }^{17}$

De oppositie van de ambachtsdekens lijkt dus mede ingegeven door economische motieven. Zuid-Nederlandse handelaars kampten met het wegvallen van afzetgebieden, waaronder het Iberisch Schiereiland, en met hoge exporttarieven. Enkele vitale stedelijke industrieën zoals de Brusselse lakenproductie zaten in het slop en het bevolkingstal van de Zennestad daalde in de eerste helft van de achttiende eeuw gestaag. Op deze economische voedingsbodem van onrust entte zich de politieke ontevredenheid over het aanvullend reglement. ${ }^{18}$ Bovendien kan de reactie van de regeringen in Brussel en Wenen op zijn minst onhandig worden genoemd, wat in de volgende alinea's zal blijken. Er was dus een cocktail van oorzaken, al is er meer onderzoek nodig naar de professionele en sociale achtergrond van de voornaamste actievoerders om uitsluitsel te brengen over hun persoonlijke motieven. Er lijkt evenwel geen verband te zijn geweest tussen de gistende onrust in Brussel en de wissel van de macht in de Zuidelijke Nederlanden. Van een algemene onvrede met het nieuwe Oostenrijkse regime was er geen sprake. ${ }^{19}$

16. Goswin Arnould de Wynants aan Prié, 20 augustus 1717: Brussel, Algemeen Rijksarchief [ARA], Departement van de Nederlanden van de Hof-en Staatskanselarij te Wenen [DN], 626, fol. 149-154v.

17. Rekwesten van de Brusselse schepenbank aan gevolmachtigd minister graaf Königsegg-Rothenfels en aan Prié: Vorst, Rijksarchief te Brussel [RAB], Officie-fiscaal van de Raad van Brabant-Registers [Officie-fiscaal RVB], 312, fol.5-5v en 7-9v; zie ook VAN GELDER K., Regime Change... op.cit., p. 213-216.

18. BANNEUX P., Un épisode... op.cit., p. 1-19; DE PEUTER, R., Brussel in de achttiende eeuw. Sociaal-economische structuren en ontwikkelingen in een regionale hoofdstad, Brussel, 1999, p. 25-34 en 298-300.

19. Met deze opinie wijk ik af van Paule Banneux, die zich in grote mate baseert op de eenzijdige rapporten van de Franse diplomaat markies de Rossi in Brussel. 
In 1717 groeiden de spanningen allengs. Terwijl de Wijde Raad en de Negen Naties hun instemming met een nieuwe vorstelijke bede weigerden, zocht gevolmachtigd minister Ercole Turinetti, markies van Prié, in mei zijn toevlucht tot een wetsverzetting. ${ }^{20}$ De vervanging van het stadsbestuur betrof niet enkel de schepenbank, ook de dekens in de Negen Naties werden afgelost. Prié hoopte zo de corporatieve tegenstand te breken, hij opende echter een doos van Pandora. De nieuwe natiedekens weigerden namelijk de eed van gehoorzaamheid aan het aanvullend reglement te zweren. Wat volgde waren maanden van oplopende spanning. Meerdere bemiddelingsrondes om een uitweg uit de impasse te vinden, bleken een maat voor niets. Juridisch betekende het uitblijven van de eed dat er niet over de beden kon worden gestemd. Dit bracht Prié in verlegenheid aangezien de financiële noden van de regering groot waren en de meeste kassen leeg. Hij verkondigde echter dat de Naties zich door de eedweigering buitenspel hadden gezet. Zijns inziens kon de bedeprocedure nu zonder hen worden verdergezet. Toch wenste de minister voor hun al dan niet tijdelijke uitschakeling. juridische rugdekking. Hij verzocht daarom de Raad van Brabant, het hoogste gerechtshof in het hertogdom, een decreet op te stellen. Op 11 juni verplichtte de Raad de dekens de eed te zweren op straffe van nader te bepalen sancties. Op voorstel van Prié en ondanks onenigheid in eigen rangen stelden de raadsheren op 24 juli in het grootste geheim een tweede decreet op. Dat hief de Negen Naties op zolang de gewenste eed uitbleef. ${ }^{21}$

20. Prié was gevolmachtigd minister en als dusdanig de vertegenwoordiger van keizer Karel VI in afwachting van de komst van landvoogd Eugenius van Savoye. Die zette tijdens zijn ambtsperiode (1716-1725) echter nooit voet op Zuid-Nederlandse bodem, waardoor Prié in Brussel de hoogste gezagvoerder was tijdens de opstand: VAN GELDER K., Prié, Ercole Giuseppe Luigi Turinetti, markies van, gevolmachtigd minister in de Zuidelijke Nederlanden, in NBW, vol. 21, Brussel, 2014, kol. 898-904.

21. Beide decreten kunnen worden gevonden in: ARA, Raad van State [RVS], 378 , fol. 11 en fol. 57-57v. Pas in september werd het zeer gevoelige decreet van 24 juli openbaar gemaakt: GACHARD L.-P., Documents inédits concernant les troubles de la Belgique sous le règne de l'Empereur Charles VI, Brussel, 1838, vol. 1, p. 36; BANNEUX P., Un épisode du gouvernement de Prié... op.cit., p. 68-69. 
Van bij het begin drong Prié aan op troepenversterkingen en op represailles tegen de dekens, die ongestoord medestanders ronselden in de stad. ${ }^{22}$ Lange tijd riep hij echter in de woestijn. De overige functionarissen en instellingen die mee het beleid uitstippelden, reageerden voorzichtiger. Landvoogd Eugenius van Savoye, keizer Karel VI en de Geheime Konferenz ${ }^{23}$ waren voorstander van een gematigd optreden. Het Oostenrijkse regime moest zich door mildheid bij de Zuid-Nederlanders geliefd maken. Een militair optreden was uit den boze. Van een eensgezinde houding tegenover de dekens was er in 1717 en begin 1718 dus allesbehalve sprake. ${ }^{24}$ Pas toen de oppositie niet bleek te verstommen, zetten zij de deur op een kier voor hardere maatregelen, al bleven zij een compromis verkiezen. ${ }^{25}$

De kentering kwam er toen het verzet escaleerde. In mei en in juli 1718 kwam het tot gewelddaden in de Brusselse binnenstad. ${ }^{26}$ Het passieve verzet van de dekens werd een onbeheersbaar oproer waaraan grote groepen mensen deelnamen. Op 24 mei ondernam Prié een zoveelste poging om de dekens de eed op het aanvullend reglement te laten zweren. Frans Van Ypen, een deken uit het tinen loodgietersambacht, was de enige die zwichtte. Toen dat nieuws

22. Prié aan Eugenius van Savoie, 7 mei en 7 juni 1717: Wenen, Haus-, Hof- und Staatsarchiv [HHStA], Belgien DD A-Berichte [Berichte], 2.

23. De Geheime Konferenz was de hoogste adviesraad in Wenen voor de hele monarchie terwijl de Hoge Raad der Nederlanden, die ook in Wenen zetelde, beleidsvoorstellen formuleerde specifiek voor de Zuidelijke Nederlanden.

24. Eugenius van Savoye aan Prié, 30 januari, 31 maart en 21 en 29 mei 1717: HHStA, Belgien DD B - Indices, Protokolle, Verzeichnisse, Inventare [Indices], 32, fol. 98-99, 149v-150, 187-187v en 196-196v; Eugenius van Savoye aan Karel VI, 29 december 1717: ARA, DN, 36; consult van de Geheime Konferenz, 20 mei 1717, met de goedkeuring van Karel VI in de marge: ARA, DN, 587.

25. Consult van de Geheime Konferenz, 16 januari 1718: ARA, DN, 587; Karel VI aan Eugenius van Savoye, 28 januari (twee depêches) en 2 februari 1718: ARA, DN, 29, fol. 237-239, ARA, DN, 628, fol. 81-85v, en HHStA, Belgien DD A-kaiserliche Depeschen [Depeschen], 2; Karel VI aan de Hoge Raad der Nederlanden, 28 januari 1718: ARA, DN, 29, fol. 239-245v.

26. Het meest gedetailleerde eigentijdse verslag van de plunderingen is de akte van beschuldiging van maart 1719 door de Raad van Brabant, uitgegeven door Louis Galesloot met een Franse vertaling: GALESLOOT L., Procès de François Anneessens, doyen du corps des métiers de Bruxelles, Brussel,1862, vol. 1, p. 1-133. 
bekend raakte kon hij ternauwernood het stadhuis ontvluchten, achternagezeten door een woedende menigte. De vernieling van zijn huis kon op het nippertje door soldaten worden afgewend. Daarop richtten de oproerlingen hun toorn op het huis van burgemeester Jean Baptiste Aurèle à Walhorn, bijgenaamd Decker. Hij werd gezien als het schoothondje van de regering en was onder de dekens weinig populair. Om erger te voorkomen liet Prié het garnizoen in de stad enkele strategische punten bezetten en het belegerde stadhuis verdedigen. Wegens het numerieke overwicht van de opstandelingen moest hij de schuttersgilden inschakelen om de soldaten bij te staan. ${ }^{27}$ Toch moest hij onder druk van de Raad van State en van verontruste Brusselaars de dekens daags nadien toelaten een voorlopige eed te zweren op het voor hen voordeliger stedelijk reglement van 1619 . De actievoerders behaalden hun eerste overwinning. ${ }^{28}$

$\mathrm{Na}$ deze toegave ontstond er een gespannen rust. In feite was het stilte voor de storm. Beide partijen groeven zich namelijk dieper in hun loopgraven in. De Raad van State en de Hoge Raad der Nederlanden schaarden zich voor het eerst achter de gerechtelijke vervolging van een selecte groep opstandelingen. Priés voorstel om alle centrale bestuursinstellingen uit Brussel weg te halen en naar een andere stad te verhuizen, vond evenwel geen bijval. Evenmin vond hij steun voor zijn plan om in Brussel een citadel op te richten. ${ }^{29}$ Intussen dreven de dekens hun eisen verder op. $\mathrm{Zij}$ weigerden een definitieve eed te zweren zolang de decreten van de Raad van Brabant van 11 juni en 24 juli 1717 niet werden ingetrokken. Ook wilden zij dat het stedelijk

27. Prié aan maarschalk Vehlen, 24 mei 1718, en aan Eugenius van Savoye, 28 mei 1718: ARA, Secretarie van State en Oorlog [SSO], 908, fol. 106-106v en ARA, DN, 626, fol. 326-345v.

28. Prié aan de schepenbank van Brussel, 25 mei 1718: ARA, DN, 626, fol. 345. Voor het reglement van 25 oktober 1619, zie: BRANTS V., Recueil des ordonnances des Pays-Bas. Règne d'Albert et Isabelle, 1597-1621. Tome deuxième contenant les actes du 8 mai 1609 au 14 juillet 1621, Brussel, 1912, p. 450-457. Dit reglement beperkte de achterraad tot de uitgaande dekens, maar in vergelijking met het reglement uit 1700 (1 deken per ambacht) was dat een veelvoud.

29. Resolutie van de Raad van State, 4 juni 1718, en consult van de Hoge Raad der Nederlanden, 12 juli 1718: ARA, RVS, 92, p. 11-12 en ARA, DN, 628, fol. 108-125v. 
reglement van 1481 werd heringevoerd, wat hun politieke speelruimte aanzienlijk zou vergroten. Op het eerste punt gaf Prié toe, opnieuw onder druk van de Raad van State. In plaats van de gemoederen te bedaren, putten de dekens uit deze zege echter moed voor verdere claims. Zo wensten zij dat de gewraakte decreten niet alleen door Prié ongeldig werden verklaard, maar dat de Raad van Brabant ze formeel uit zijn registers zou schrappen. ${ }^{30}$

Op 17 juli ging de jaarlijkse processie van het Sacrament van Mirakel uit. Voor die gelegenheid waren vele bezoekers van buiten de stad toegestroomd. De vrees bestond dat het tijdens de processie tot onlusten zou komen. Die vrees bleek ongegrond, maar twee dagen later kwam de uitbarsting er toch. Veel sympathisanten van de dekens meenden namelijk dat de verordeningen, die hun eisen inwilligden, niet op een correcte manier waren afgekondigd. Het wantrouwen tegen de overheid was groot en het kwam tot nieuwe geweldplegingen. Op 19 juli werden onder andere het huis van de kanselier van Brabant en de kanselarij zelf geplunderd. Als voorzitter van de Raad van Brabant die de opheffing van de Negen Naties had bewerkstelligd, was kanselier Guillaume Albert de Grysperre voor de opstandelingen kop van jut. Op 20 juli ondergingen de huizen van de Brusselse schepenen Cano en Lasso, de pensionaris van de Staten van Brabant Vandenbroeck en de abt van de abdij van Dielegem hetzelfde lot. Stuk voor stuk werden zij met het gehate overheidsoptreden geassocieerd. Ook in augustus en september bleef de situatie in Brussel gespannen. Geregeld waren er nieuwe opstootjes en plunderingen. ${ }^{31}$

30. Prié aan Eugenius van Savoye, 18 juli 1718: HHStA, Berichte, 4; decreet van de Raad van Brabant, 8 juli 1718: ARA, RVS, 378, fol. 255. De Brusselse magistraat verzocht Prié de decreten van juni en juli 1717 te annuleren, wat Prié op 16 juli 1718 deed: RAB, Officie-fiscaal RVB, 312, fol. 101-101v en 105-105v. Prié beval de Raad van Brabant uiteindelijk om de decreten te schrappen uit de registers en ongeldig te verklaren, wat op 19 juli gebeurde. Op 20 juli, om 7u's morgens, werden de cassatieakten op de kleine pui van het stadhuis geafficheerd: RAB, Raad van Brabant-Griffies [RVB - Griffies], 5284, marginale nota bij het decreet van 11 juni 1717.

31. BANNEUX P., Un épisode... op.cit., p. 132-133 en 143-165. 
De gebeurtenissen van mei en juli 1718 zetten het regime met de rug tegen de muur. De nijpende financiële situatie waarin Prié moest optreden werd door de bedeweigering nog verscherpt. ${ }^{32}$ Tegelijk bleef de nood aan soldaten groot. In oktober 1717 was het garnizoen al met dragonders en grenadiers uitgebreid, in totaal 1300 à 1400 bijkomende manschappen. Toch volstond dit niet. Pas in november $1718 \mathrm{kwamen}$ extra infanteristen en cavaleristen aan. $\mathrm{Zij}$ hadden in de kort voordien beëindigde oorlog tegen de Ottomanen gestreden en konden nu pas in de Nederlanden worden ingezet. ${ }^{33}$ Zolang Prié over onvoldoende soldaten beschikte, had hij voorzichtige maatregelen genomen om de situatie beheersbaar te houden. Dit verklaart zijn toegevingen aan de opstandelingen. De plunderingen schrikten echter heel wat burgers op. De situatie liep uit de hand en de dekens verloren de controle. In dat klimaat verkoos het stadsbestuur maatregelen om de rust te laten weerkeren en de aanstokers van het geweld te vervolgen. De schepenbank begon met Prié samen te werken en voorzag voortaan diens besluiten van de nodige autoriteit. ${ }^{34}$

De bovenstaande alinea's tonen aan hoeveel actoren een rol speelden in de opstand en het bedwingen ervan. Aan de kant van de actievoerders waren er de politiek actieve dekens met een middenklasse-achtergrond en met contacten in het stadsbestuur en zelfs in regeringskringen. Zij werden gesteund door grote groepen medestanders, waaronder vermoedelijk heel wat arme Brusselaars en ontevreden bewoners van het omliggende platteland. ${ }^{35}$ Prié was er vast van overtuigd dat de op-

32. Over de grote geldnood van het Oostenrijks regime onder Karel VI: VAN GELDER K., Regime Change... op.cit., p. 243-263; HASQUIN H., Les difficultés financières du gouvernement des Pays-Bas autrichiens au début du XVIII e siècle (17171740), in Revue internationale d'Histoire de la Banque, vol. 6, 1973, p. 100-133.

33. BANNEUX P., Un épisode... op.cit., p. 71 en 170.

34. VAN GELDER K., Markies van Prié en het Brusselse oproer in 1717-1719. Over de repressie en de slagkracht van het centrale gouvernement in de Zuidelijke Nederlanden, in Tijdschrift voor Geschiedenis, vol. 127, deel 3, 2014, p. 381.

35. De middenklasse met een zekere welstand en scholing vervulde in heel wat stedelijke opstanden een eersterangsrol. Een standaardwerk terzake is DAMBRUYNE J., Corporatieve middengroepen: aspiraties, relaties en transformaties

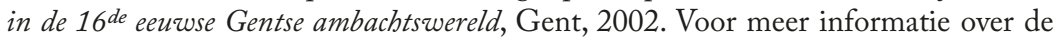
moeilijk traceerbare massa, die vaak als stoottroepen van de verzetsleiders fungeerde 
standelingen achter de schermen de steun genoten van invloedrijke edelen, een groep met wie hij op gespannen voet leefde. Voor deze bewering is er echter geen concreet bewijs. ${ }^{36}$ Ook aan de kant van de overheid waren er verschillende actoren, zowel in Brussel als in Wenen. In de Zennestad hadden zowel de magistraat (lokaal niveau), de Raad van Brabant (gewestelijk niveau) als de Raad van State ${ }^{37}$ en de gevolmachtigd minister (centraal niveau, bevoegd voor de hele Zuidelijke Nederlanden) een vinger in de pap. Daarnaast speelde het leger een onmiskenbare rol. Prié beschikte over onvoldoende soldaten om snel voor een harde repressie te opteren. Ook leefde hij op gespannen voet met de opperbevelhebber, maarschalk Vehlen, wat de snelle inzetbaarheid van de troepen verhinderde..$^{38}$ Daarnaast was Brussel niet de enige onrustige stad, ook in Antwerpen en Mechelen braken er in 1718 onlusten uit. ${ }^{39}$ Bovendien was Prié ondanks zijn harde toon een te voorzichtig politicus om vastberaden de koe bij de horens te vatten. ${ }^{40} \mathrm{Zijn}$ twijfels werden nog versterkt door lobbywerk ten voordele van de dekens, onder andere vanwege de Raad van Brabant. ${ }^{41}$ Prié zocht voor zijn beslissingen steun in Wenen, maar de keizer, de landvoogd, de Hoge Raad der Nederlanden noch de Geheime Konferenz

(weliswaar met focus op de Late Middeleeuwen): DUMOLYN J., Marginalen of radicalen? Het vertoog over de 'roepers en krijsers' tijdens stedelijke opstanden, voornamelijk in het laatmiddeleeuwse Vlaanderen, in Tijdschrift voor Sociale en Economische Geschiedenis, vol. 2, deel 2, 2005, p. 29-53.

36. Ook Paule Banneux gaat uit van adellijke steun achter de schermen, maar kan die stelling niet overtuigend staven (cf. p. 66, 228-272 en 298 van haar proefschrift). Wel lijken enkele edelen met een zitje in de Raad van State een kordate repressie te hebben tegengewerkt: resolutie van de Raad van State, 25 mei 1718: ARA, RVS, 92, p. 4-5; Prié aan Eugenius van Savoye, 18 juli 1718: HHStA, Berichte, 4; VAN GELDER K., Markies van Prié... op.cit., p. 386. Anneessens gaf tijdens zijn verhoor toe contact te hebben gehad met hertog d'Ursel, een raadsheer van State, weliswaar met het doel de gespannen situatie te ontzenuwen: GALESLOOT L., Procès... op.cit., vol. 1, p. 180-184.

37. Tot de (her)oprichting van de Raad van State in maart 1718 werd Prié bijgestaan door een voorlopige regeringsjointe die hem inzake de Brusselse opstand adviseerde. 38. BANNEUX P., Un épisode... op.cit., p. 46, 104-105, 110, 112, 131 en 259-262; VAN GELDER K., Regime Change... op.cit., p. 222-224.

39. VAN GELDER K., Regime Change... op.cit., p. 222-223 en 235-238.

40. BANNEUX P., Un épisode... op.cit., p. 53, 59 en 81-82; VAN GELDER K., Markies van Prié... op.cit., p. 378-381.

41. BANNEUX P., Un épisode... op.cit., p. 74-75. 
waren bereid de minister onvoorwaardelijk te steunen. Bovendien had Wenen met de oorlog tegen de Ottomanen andere katten te geselen. Op instructies van het hof was het daarom vaak maandenlang wachten en Prié was er de man niet naar om in dat vacuüm groot leiderschap te tonen. Kortom: een waaier aan actoren met elk een eigen agenda en een eigen inschatting van het gebeuren verhinderde een eendrachtig overheidsoptreden. Tel daarbij de geldnood van het regime, de onlusten in andere steden, de afstand tussen Wenen en Brussel - voor de overdracht van rapporten of decreten tussen beide steden moest er minstens een week worden gerekend - en de woelige internationale politiek, en het is duidelijk waarom de gildedekens in 1718 hun eisen steeds verder konden opdrijven, net als in 1699 .

\section{Repressie, gratie, en het geval Anneessens}

Aan de afwachtende houding van het hof in Wenen kwam in december 1718 een eind. Met de Vrede van Passarowitz van 21 juli 1718 was de oorlog met de Ottomanen glansrijk afgesloten. Niet alleen konden nu troepen naar de Nederlanden worden gestuurd42, ook kon Wenen zich eindelijk weer op andere dossiers concentreren. Op 3 december ondertekende Karel VI niet minder dan zes depêches om komaf te maken met de onlusten in Brussel. Hij herriep alle decreten die tijdens het oproer onder dreiging van geweld waren uitgevaardigd en verplichtte de dekens de eed op het aanvullend reglement te zweren. Het officie-fiscaal van de Raad van Brabant kreeg het bevel vervolgingen in te stellen en de raad zelf werd aangemaand strenge straffen uit te spreken. Het officie-fiscaal moest zich echter beperken tot een klein aantal kopstukken en Prié moest de dekens overreden om vorstelijke genade in te roepen.43 Dat laatste paste in een verzoeningsstrategie die op lange termijn te verkiezen was boven aanhoudende rancune. Het Oostenrijks regime was nieuw en miste vooralsnog een stevige

42. Tegen maart 1719 waren er zo'n 9000 soldaten in Brussel gestationneerd: Ibidem, p. 194.

43. Zes keizerlijke depêches van 3 december 1718: HHStA, Depeschen, 2. 
lokale verankering. Dit verklaart waarom Karel VI tegelijk wilde slaan en zalven.

Bijna het hele jaar 1719 stond in het teken van de rechtsgang tegen de dekens en de plunderaars. Aangezien opstand tegen de vorst als majesteitsschennis werd gekwalificeerd, was de Raad van Brabant als hoogste vorstelijk gerechtshof in het hertogdom bevoegd. De schrik voor represailles zat er bij de raadsheren echter diep in. De vernieling van de kanselarij lag nog vers in het geheugen en sinds de zomer lagen de werkzaamheden stil. ${ }^{44}$ Pas in januari hervatte de raad het werk. Via advocaat-fiscaal Antoine François Charliers was Prié op de hoogte van de interne besprekingen en de opinies van de afzonderlijke raadsheren, onder wie er haviken en duiven waren. Prié kwam haast wekelijks samen met Charliers, rapporteur Philippe Clériade du Chêne (du Chesne) en raadsheer van State Hubert de Tombeur ${ }^{45}$ om de voortgang van het gerechtelijk onderzoek te bespreken. Via deze gesprekken trachtte Prié de raadsheren tot een snellere rechtsgang te bewegen en de uitkomst van de processen te beïnvloeden. ${ }^{46}$

Een voorval op 30 en 31 januari 1719 toont hoezeer de toon intussen was verhard. Tijdens een carnavaleske optocht werden leuzen gescandeerd ten voordele van Filips V - keizer Karels tegenstrever tijdens de Spaanse Successieoorlog. Meerdere arrestaties werden verricht en ditmaal riepen zowel de keizer, de Hoge Raad der Nederlanden als de Geheime Konferenz op tot een snel en doortastend optreden. De keizer bekritiseerde Prié: hij zou de depêches van december 1718 te traag

44. De meest uitgebreide bespreking van de activiteiten van de Raad van Brabant tijdens de Brusselse opstand blijft GAILLARD A., Le Conseil de Brabant. Histoire - Organisation - Procédure, vol. 1 (Histoire), Brussel, 1898, p. 266-281. Zie ook het consult van 21 april 1719 over de herneming van de activiteiten: RAB, RVB - Griffies, 5226, fol. 128.

45. Diens zoon met dezelfde voornaam was sinds 1716 raadsheer in de Raad van Brabant.

46. Voor een analyse van Priés beïnvloeding en de grenzen van zijn mogelijkheden om de rechtsgang van de raad te sturen: VAN GELDER K., Markies van Prié... op.cit., p. 381-387. Zie ook: GALESLOOT L., Procès... op.cit., vol. 1, p. xxviii-xliii. 


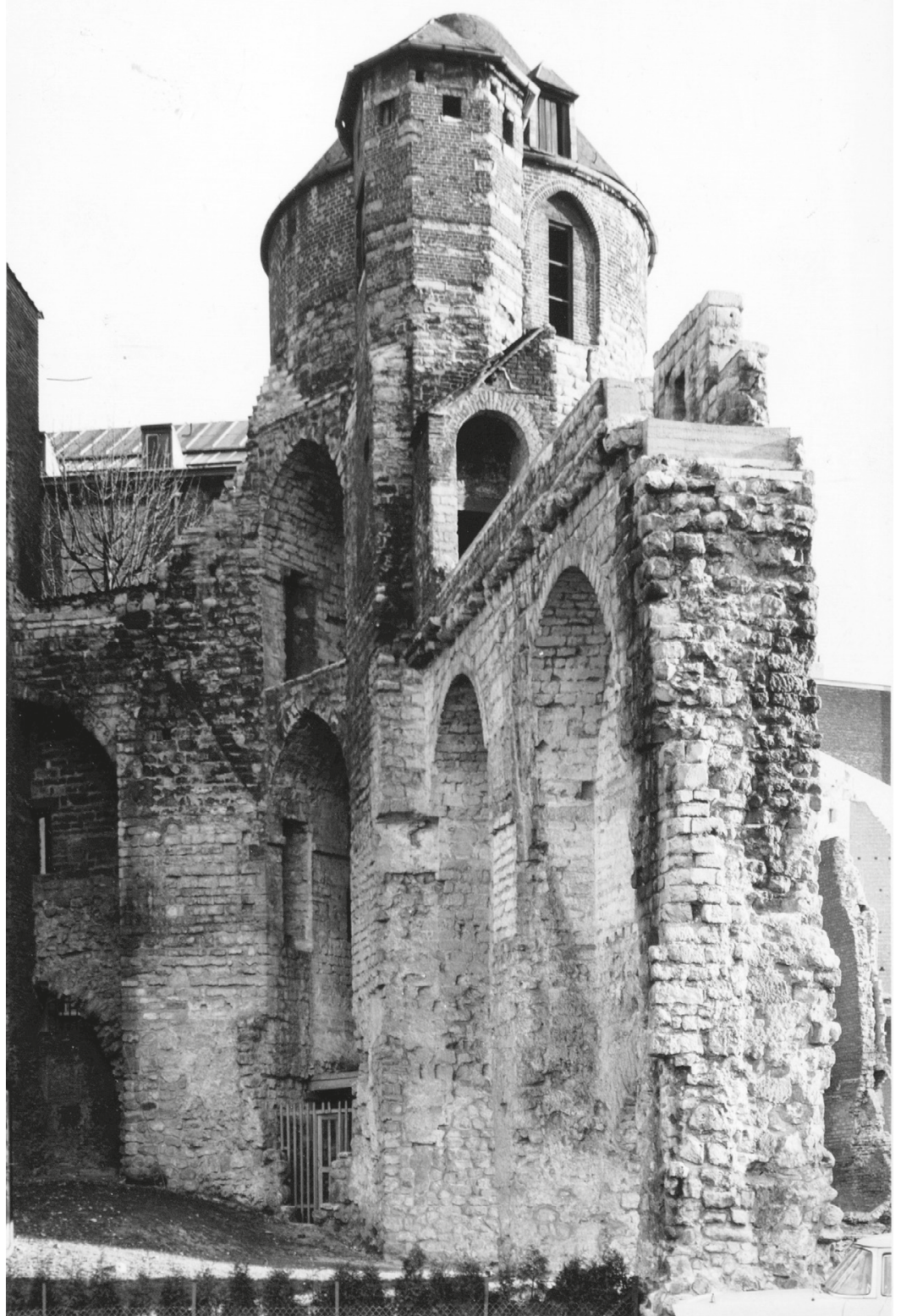

I11. 1: "Steenpoort, deel van de eerste Brusselse stadsomwalling waar Frans Anneessens en zijn collega-dekens in 1719 in hechtenis werden genomen" (A.V.B.| A.S.B., I.V., C-12973). 
ten uitvoer hebben gebracht. ${ }^{47}$ Nochtans drong Prié er meermaals bij het officie-fiscaal op aan om met de vervolging te starten en streng te zijn. ${ }^{48}$ Ook had hij in februari een edict uitgevaardigd dat vagebonden verplichtte binnen de achtenveertig uur de stad te verlaten. Enkele dagen later werden cabaretten gecontroleerd en een veertigtal arrestaties verricht. Met een vorm van snelrecht werden de arrestanten berecht en vervolgens gegeseld, gebrandmerkt en verbannen. ${ }^{49}$

Op 14 maart vaardigde de Raad van Brabant een aanhoudingsbevel uit tegen de elf hoofdverdachten van de opstand. Diezelfde dag werden de boetmeesters Anneessens, François Lejeusne (Le Jeune) en Joannes Franciscus Vander Borcht (Vander Borght), ambachtsdeken Adriaen Coppens en oud-deken Gabriel De Haeze gearresteerd en in de Steenpoort in hechtenis genomen. De zes resterende boetmeesters waren tijdig de stad ontvlucht. In juni 1719 werden vervolgens een twintigtal plunderaars ingerekend. ${ }^{50}$ De gevangen ambachtsmeesters werden van meerdere misdrijven beschuldigd: het aanzetten tot bedeweigeringen, het niet zweren van de eed op het aanvullend reglement (wat als een plicht werd beschouwd), het gewapenderhand laten schrappen van de decreten die de Naties nietig verklaarden en het niet verhinderen maar integendeel aanzwengelen van onlusten en plunderingen. De namen van Anneessens, Lejeusne, Vander Borcht en De Haeze worden in het aanhoudingsbevel heel frequent genoemd en met meerdere aanklachten in verband gebracht. Ook benadrukt het officie-fiscaal dat de overheid talloze toegevingen had gedaan.

47. VAN GELDER K., Regime Change... op.cit., p. 227-228.

48. Decreten van Prié aan het officie-fiscaal van 4 en 27 maart 1719: RAB, Officiefiscaal RVB, fol. 140 en 147.

49. BANNEUX P., Un épisode... op.cit., p. 174.

50. Alle procesakten tegen Anneessens en de andere gevangen ambachtsdekens worden bewaard in RAB, Officie-fiscaal RVB, 313. De processtukken over Anneessens werden uitgegeven en naar het Frans vertaald: GALESLOOT L., Procès... op.cit., vol.1 (p.1-133 voor het aanhoudingsbevel). De meest uitvoerige beschrijving van het proces levert BANNEUX P., Un épisode... op.cit., p. 203-227. De boetmeester (syndic in het Frans) was binnen de Natie verantwoordelijk voor de ordehandhaving. Daarvoor kon hij boetes uitschrijven. Daarnaast was hij de contactpersoon en officiële spreekbuis van de Natie met de overheid, wat de belangrijke rol van iemand als Anneessens in de opstand helpt verklaren. 
Op aandringen van Anneessens, Lejeusne en Vander Borcht had de schepenbank zelfs enkele gevangen plunderaars opnieuw vrijgelaten.

Het aanhoudingsbevel bevat geenszins een objectief relaas van de feiten. Het taalgebruik verraadt een enorme afkeer voor de daden van de beschuldigden. Er is sprake van "wederspannigheyt", "openbaere versmaedinge van de princelycke beveelen", "onverdraeghelycke insolentie", "dit infaem en schrickelyck werck" en "enorme excessen". Met hun acties hadden de gevangenen een gebrek aan respect getoond voor bevelen van hogerhand, de regering beledigd, de Raad van Brabant mishandeld, de Staten van Brabant geweld aangedaan, de magistraat verstoord en de hele stad in gevaar gebracht. $Z_{i j}$ hadden de heilige plaats van justitie onteerd, waarmee de plundering van de kanselarij werd bedoeld. Ook werden de opstandelingen als een redeloze bende afgeschilderd. Het zijn stuk voor stuk bewoordingen die passen in een eeuwenoud discours. Machthebbers pleegden opstandelingen voor te stellen als een woeste bende die de bestaande orde wilde omverwerpen en chaos en verderf bracht. ${ }^{51}$

Anneessens werd op 28, 29 en 30 maart en tenslotte op 25 mei ondervraagd. In totaal duurden zijn verhoren ruim twintig uur. ${ }^{52}$ Als motief voor zijn eedweigering haalde hij aan dat het aanvullend reglement niet door Karel II was ondertekend. Zijns inziens was het pas in werking getreden onder Filips V, wiens regeerperiode, het zogenoemde Anjouaanse Regime, hij een usurpatie noemde. Daar de keizer de ordonnanties en reglementen uitgevaardigd door Filips V ongeldig had verklaard, meende Anneessens dat de eedweigering op het aanvullend reglement gerechtvaardigd was. ${ }^{53}$ Verder verdedigde hij

51. Zie daarvoor het hogerop geciteerde artikel van Jan Dumolyn: DUMOLYN J., Marginalen of radicalen... op. cit.

52. Ondervraging in: RAB, RVB - Griffies, 313, fol. 88-105v; GALESLOOT L., Procès... op.cit., vol. 1, p. 135-251.

53. Van een annulering van alle onder Filips $V$ uitgevaardigde verordeningen was onder Karel VI echter geen sprake. Slechts bepaalde categorieën, zoals benoemingen en eerbewijzen, werden herroepen, en zelfs die beslissing werd niet consequent uitgevoerd: VAN GELDER K., De Vooght versus Sersanders. De strijd om het presidentschap van de Raad van Vlaanderen en het probleem van de 'Anjouaanse' benoemingen in de Oostenrijkse 
zich door te stellen dat het decreet van de Raad van Brabant van 11 juli 1717, dat de Naties tijdelijk buitenspel had gezet, niet volgens de geijkte regels aan de Naties was meegedeeld. Ook had hij de doorschrapte decreten niet uit eigen beweging door de Brusselse straten gedragen, maar op uitnodiging van de schepenbank. De schepenen hoopten zo de gemoederen te bedaren. Tenslotte ontkende Anneessens enig aandeel in de plunderingen te hebben gehad. Hij had daarentegen pogingen ondernomen om het geweld in te dijken of te beletten.

Anneessens'verzoek om tijdens het proces bijgestaan te worden door een advocaat en een procureur werd door het hof afgewezen. De rechtszaak werd volgens de extraordinaire criminele procedure gevoerd en daar kwamen in de Raad van Brabant normaliter geen advocaten aan te pas. ${ }^{54}$ In de loop van de verhoren stelde Anneessens ook dat zijn arrestatie niet volgens het boekje was verlopen aangezien het aanhoudingsbevel bij zijn arrestatie nog niet uitgevaardigd was. Bovendien had men bij zijn aanhouding de orders daartoe niet kunnen tonen. Dat druiste in tegen artikel 1 van de Blijde Inkomst. ${ }^{55}$ Louis Galesloot kon deze beweringen tijdens zijn uitgebreide archiefonderzoek niet verifiëren. Hij vermoedt echter dat de Raad van Brabant nauwgezet de procedureregels respecteerde om de spanningen niet verder te laten oplopen en nieuwe gewelddaden te vermijden. Prié ergerde zich overigens blauw aan deze strikte inachtneming van de procedure, maar

Nederlanden (1716-1725), in Pro Memorie, vol. 12, deel 1, 2010, p. 15-35.

54. Tussenvonnis van de Raad van Brabant, 27 mei 1719, in: GALESLOOT L., Procès... op.cit., vol. 1, p. 254-256. De extraordinaire criminele procesgang vond onder andere plaats als de strafrechters meenden dat het vooronderzoek ('informatie preparatoire') voldoende aanwijzingen voor schuld had opgeleverd. Hoewel Anneessens veel van de beschuldigingen ontkende, gingen de Brabantse raadsheren hier in zijn geval dus ook van uit: MONBALLYU J., Het onderscheid tussen de civiele en de criminele en de ordinaire en de extraordinaire strafrechtspleging in het Vlaamse recht van de $16^{e}$ eeuw, in DIEDERIKS H.A., ROODENBURG H.W. (red.), Misdaad, zoen en straf. Aspekten van de middeleeuwse strafrechtsgeschiedenis in de Nederlanden, Hilversum, 1991, pp. 120-132.

55. Tussenvonnissen van de Raad van Brabant, 17 juni 1719, in: GALESLOOT L., Procès... op.cit., vol. 1, p. 258-268. 
was niet in staat de raadsheren te vermurwen. Evenmin kon hij hen overhalen de dekens onder tortuur te ondervragen. ${ }^{56}$

Heel wat van de door Anneessens opgeroepen getuigen weerlegden de beschuldigingen aan zijn adres. Zij onderstreepten hoe de boetmeester zich had uitgesloofd om de plunderingen te voorkomen of op zijn minst in te dijken. ${ }^{57}$ Desalniettemin veroordeelde de Raad van Brabant hem op 9 september ter dood. ${ }^{58}$ De verzoekschriften van verwanten, vrienden en collega's van de dekens om genade te tonen, haalden niets uit. ${ }^{59}$ Keizer Karel VI maakte uiteindelijk een onderscheid tussen drie groepen beschuldigden. Ten eerste waren er de plunderaars. Hun straffen moesten worden uitgevoerd, al kreeg Prié de vrijheid om gratie te verlenen aan terdoodveroordeelden. ${ }^{60}$ Daarnaast was er de categorie van de gearresteerde dekens. Zij moesten worden veroordeeld tot verbanning en confiscatie van goederen. Indien De Haeze of Anneessens - die als de leiders van de opstand werden gezien - de doodstraf kregen, moest Prié hun misdrijven onder de loep nemen. Als hij de daden van een van hen zwaarder inschatte dan die van de ander, moest één doodstraf worden uitgevoerd. De straf van de andere kon dan in een eeuwige verbanning worden omgezet. Tenslotte waren er nog de deelnemers aan de optocht in januari 1719. Hun vermoedelijk lichte straffen moesten eveneens worden uitgevoerd. ${ }^{61}$

56. VAN GELDER K., Markies van Prié... op.cit., p. 384-385; BANNEUX P., Un épisode... op.cit., p. 207 en 209.

57. Voor de getuigenverhoren, zie: RAB, RVB - Griffies, 313, fol. 114-132; GALESLOOT L., Procès... op.cit., vol. 1, p. 290-367.

58. In de maanden voordien haden zowel de Geheime Konferenz als de Hoge Raad der Nederlanden steeds hardere sancties geëist: consulten van de Geheime Konferenz, 18 en 25 juli 1719 (ARA, DN, 587) en van de Hoge Raad der Nederlanden, 20 juli 1719 (ARA, DN, 628, fols. 215-223v).

59. Zie onder andere het verzoekschrift tot vrijlating van Anneessens door diens zoon Johannes Andreas: Archief van de stad Brussel, historisch archief, lias 609. Zie ook BANNEUX P., Un épisode... op.cit., p. 191-192, 200-201 en 208.

60. Anthoen Wets en Alexis De Drijver kregen genade toen ze naar de galg werden gebracht. Hun straf werd omgezet in geseling en eeuwige ballingschap: GALESLOOT L., Procès... op.cit., vol. 1, p. 100-101 en 109 (voetnoten).

61. Karel VI aan Eugenius van Savoye, 2 en 16 augustus 1719 (HHStA, Depeschen, 3). 
In de sententie wordt Anneessens ervan beschuldigd de eed op het aanvullend reglement te hebben geweigerd en daardoor de bevelen van de keizer te hebben genegeerd. Ook had hij aangedrongen op de vervanging van de soldaten op de places d'armes door de Brusselse wijcken - burgercompagnieën die instonden voor de bewaking van de stadsmuren en -poorten. Verder had hij, aldus de sententie, aangestuurd op het zweren van een oude eed en de annulering van de decreten van 11 juni en 24 juli 1717. De verklaring van Prié dat beide decreten niet langer geldig waren, had hij onvoldoende geacht en samen met andere boetmeesters en dekens had hij de Raad van Brabant gedwongen beide decreten formeel te schrappen uit de registers. Op basis hiervan werd Anneessens veroordeeld tot de doodstraf door onthoofding. ${ }^{62}$

Anneessens was niet de enige die door de Raad van Brabant werd bestraft. Begin september hoorden niet minder dan zevenendertig verdachten hun straf, daaronder drie vrouwen. Tien van hen zaten in hechtenis in de Treurenborg, de anderen in de Steenpoort. Voor twaalf veroordeelden werd de periode van hechtenis als een voldoende straf beschouwd. Zeven personen werden tijdelijk uit de Zuidelijke Nederlanden verbanden, tien anderen werden eeuwig verbannen, al dan niet nadat zij in het openbaar waren gegeseld en/of gebrandmerkt. ${ }^{63}$ Tenslotte bekochten acht verdachten hun aandeel in de opstand met de dood, doorgaans door ophanging op de Grote Markt. Enkel Anneessens werd onthoofd. ${ }^{64}$ Op 19 september 1719 werden de lijf- en doodstraffen uitgevoerd. Een schokgolf joeg door de stad. De sympathiebetuigingen voor de onthoofde deken waren immens. Herdenkingsmissen werden georganiseerd, kerkklokken luidden, en Frans Anneessens werd in

62. Sententie van 9 september 1719: RAB, RVB - Griffies, 956; GALESLOOT L., Procès... op.cit., vol. 2, p. 370-397.

63. Die geselingen vonden symbolisch plaats voor de plaatsen delict. Zo werd Joannes De Bruyn gegeseld voor de huizen van de burgemeester, de kanselier en raadsman De Grieck. Philippe De Dobbelaer moest op het schavot verschijnen voor het huis van schepen Cano.

64. De lezer kan een overzicht van alle beschuldigden vinden in GALESLOOT L., Procès... op.cit., vol. 2, p. 172-176. Voor de originele sententies: RAB, RVB - Griffies, 956 (vonnisboek). Nicolaes Nietens, die op 1 september voor tien jaar werd verbannen, is niet in Galesloots lijst opgenomen. 
de Brusselse Kapellekerk begraven en niet in ongewijde grond, zoals gebruikelijk was voor veroordeelde misdadigers. ${ }^{65}$

Het is moeilijk om op grond van het gerechtelijk onderzoek de ware toedracht van de feiten te achterhalen. De rechtsakten tonen de opstand door de ogen van de openbaar aanklager en de rechters. Bovendien is het maar de vraag of de antwoorden van de verdachten, die geen bijstand van een advocaat of procureur genoten en niet met elkaar werden geconfronteerd, accuraat zijn. Opmerkelijk is dat Anneessens op geen enkel moment de schuld in de schoenen van zijn collega's tracht te schuiven om zijn eigen vel te redden. Ook kan uit de ooggetuigenverslagen en uit de officiële rapporten en correspondenties worden besloten dat Anneessens onder de actievoerders een groot aanzien genoot. Hij was één van de voortrekkers van het verzet tegen het aanvullend reglement en de tijdelijke opheffing van de Negen Naties. Zijn verhoor getuigt van zijn standvastigheid en zijn vertrouwen in de Blijde Inkomst van Brabant en de billijkheid van de corporatieve eisen. Dat hij een kopstuk was blijkt ook uit Priés verbetenheid om op zijn minst Anneessens zwaar te laten boeten, al achtte Prié De Haeze minstens even schuldig.

In maart, kort na de arrestatie van de dekens, stemden de Brusselse Naties in met de beden van 1717. In juni volgde hun goedkeuring voor 1718. Op 6 februari 1720 zwoeren de Natiedekens uiteindelijk de eed op het aanvullend reglement en de decreten van de Raad van Brabant van juli 1718 werden formeel geannuleerd. Prié kon eindelijk opgelucht ademhalen, maar voldaan was hij niet. Hij wilde Brussel bestraffen door het onderhoud van de soldaten, de gerechtskosten en een compensatie voor de slachtoffers van het oproer op de stad af te wentelen. Geen enkele andere instantie was bereid Prié daarin te steunen. ${ }^{66}$ Dit past in het tweede deel van de Weense strategie

65. VAN GELDER K., Regime Change... op.cit., p. 232.

66. Fragmenten van consulten van de Hoge Raad der Nederlanden, 23 september 1720 (ARA, DN, 152, fol. 87-87v); consult van de Geheime Konferenz, 23 juni 1721 (ARA, $D N, 587)$; Eugenius van Savoye aan Prié, 31 augustus 1720 en 1 maart 1721 (HHStA, Indices, 35, fol. 123-123v en 36, fol. 31v-32v); Karel VI aan Eugenius van Savoye, 
tegenover de opstandelingen: na het slaan kwam het zalven. Het regime had zijn tanden laten zien, nu moest het tonen ook genadig te zijn. ${ }^{67} \mathrm{Om}$ die reden verkreeg Van Ypen het ambt van hoffonteinier en pensioenen voor zijn dochters. Antoine De Grieck, die als raadsman de Sint-Goriksnatie aangeraden had de kant van de overheid te kiezen en wiens huis was geplunderd, werd eerste deurwaarder in de Raad van Brabant. Verschillende slachtoffers maakten ook aanspraak op financiële compensaties voor de vernielingen die in hun huizen waren aangericht, al vielen de uiteindelijke vergoedingen een pak lager uit dan veel slachtoffers hadden gehoopt. ${ }^{68}$

Vorstelijke genade voor de bestrafte opstandelingen moest het sluitstuk van die zalvende politiek worden. Echter, tegen midden 1722 hadden de verbannen dekens nog steeds geen verzoek tot genade ingediend. Pas onder landvoogdes Maria Elisabeth, die in de herfst van 1725 in Brussel aankwam, werd gratie verleend. Zij wilde haar ambtsperiode onder een goed gesternte beginnen en drong bij de keizer aan op amnestie. Zij was het ook die De Haeze, Lejeusne en Vander Borcht in de akte van gratie liet opnemen. Enkele jaren later benoemde Maria Elisabeth Johannes Andreas Anneessens, Frans' oudste zoon, tot hofarchitect en toezichthouder van de bouwwerken aan het hof. Los van het onmiskenbare talent van Johannes Andreas was dit mogelijk ook een manier om de onthoofde ambachtsdeken, die in de akte van gratie niet werd genoemd, te rehabiliteren. ${ }^{69}$

16 november 1720 (HHStA, Depeschen, 4).

67. Eugenius van Savoye aan Prié, 18 oktober 1719 en 8 mei 1720 (HHStA, Indices, 34, fol. 206-207v en 35, fol. 72-72v); Karel VI aan Eugenius van Savoye, 17 februari 1720 (HHStA, Depeschen, 4).

68. Eugenius van Savoye aan Prié, 8 april 1719 (HHStA, Indices, 34, fol. 72v-73); Prié aan Eugenius van Savoye, 18 juni 1719 (HHStA, Berichte, 6); BANNEUX P., Un épisode... op.cit., p. 282-286.

69. Karel VI aan Maria Elisabeth, 24 september 1725, met de akte van gratie in bijlage: HHStA, Depeschen, 8. Over Johannes Andreas Anneessens: WOUTERS A., Anneessens (Jean-André), architecte, in Biographie Nationale, vol. 1 (A-B), Brussel, 1866, kol. 317-318. 


\section{Besluit: van martelaar tot metrostation, bespiegelingen bij een heldenstatus}

Het verzet van de ambachtsdekens tegen het aanvullend reglement leidde tot de laatste grote Brusselse revolte tegen het centraal gezag, maar kan in een lange traditie worden gesitueerd..$^{70}$ De oorzaak van het verzet kan direct worden gekoppeld aan de voorafgaande opstand onder Maximiliaan Emmanuel van Beieren. Bovendien waren de actiemiddelen van de opstandelingen klassiek - supporters mobiliseren op de Grote Markt, het stadhuis belegeren, beden en subsidies weigeren. Ook het in elkaar haken van de grote en kleine traditie van opstandigheid en het geleidelijk escaleren van de collectieve actie tot gewelddadig protest, kenden een lange geschiedenis. Hetzelfde geldt voor de reactie van overheidswege. Maandenlang hoopten de regeringsorganen in Brussel en Wenen op een vergelijk. Pas in 1718, toen de eed- en bedeweigering het regime pijn begonnen te doen, besloten alle bevoegde instanties dat een streng optreden vereist was. De inkomsten van de regering in Brussel hingen voor een groot deel af van het breken van het corporatieve verzet. Ook daarvoor volgde men beproefde recepten: er werden troepen naar de stad gestuurd en het gerechtelijk apparaat werd ingeschakeld. De straffen waren streng, maar eens ze uitgesproken en (deels) uitgevoerd waren, was het tijd voor verzoening. Ook dat was klassiek. Karel VI wilde regeren op basis van consensus en niet op basis van dwang. Landsbestuur gedragen door samenwerking met de lokale elites was niet zomaar een wensdroom, het was een politieke noodzaak in vroegmodern Europa. Het aanvullend reglement van 1700 werd bevestigd en er werden doodstraffen uitgevoerd, maar er kwam geen citadel in Brussel, noch werden onredelijke schadevergoedingen geëist. ${ }^{71}$

70. Ik maak een onderscheid tussen geïsoleerde stedelijke revoltes en pakweg de omwenteling in 1787-1789 tegen Jozef II. De stad Brussel speelde daarin ook een rol speelde maar die omwenteling was geografisch veel omvangrijker.

71. Ter vergelijking: ook de opstanden van 1619, 1681 en 1698-1699 werden bedwongen door middel van soldaten, gerechtelijke vervolgingen en een algemene amnestie. Hetzelfde scenario was van toepassing op de opstanden in Antwerpen en Mechelen in 1718 of de gildeopstand van 1659 in Antwerpen: VAN HONACKER K., 
Kortom, de Brusselse opstand van 1717-1718 was op weinig vlakken buitengewoon. Hij beantwoordt aan de gebruikelijke patronen van vroegmoderne stedelijke opstandigheid in de Lage Landen en de repressie ervan. Toch schonken historici uitgerekend aan deze revolte disproportioneel veel aandacht. Dat heeft te maken met de effectief uitgevoerde doodstraf van Anneessens. In de zeventiende en achttiende eeuw was de onthoofding van een opstandige ambachtsdeken, laat staan een boetmeester, een zeldzaamheid geworden. Anneessens was de laatste die dat trieste lot in de Zuidelijke Nederlanden te beurt viel. ${ }^{72}$

Zijn uitstraling moet groot zijn geweest. Meteen na zijn dood werd hij binnen ambachtsmiddens als een martelaar vereerd. Tientallen elegieën en herdenkingsmissen werden aan hem opgedragen. Pas eind achttiende eeuw werd echter voor het eerst de geschiedenis van de Brusselse opstand neergepend. Het corporatieve perspectief dat Anneessens' daden verheerlijkte en Prié en burgemeester Decker verketterde, was toen slechts een van de zienswijzen. De romantisch getinte nationale geschiedschrijving, die haar bloei kende tussen 1830 en 1850, verdrong de overige narratieven echter grotendeels naar de achtergrond. De mythologisering van Frans Anneessens nam een hoge vlucht. Hij werd voorgesteld als een moedig vrijheidsstrijder, het slachtoffer van de despotische Oostenrijkse overheersers. Andere gezichtspunten werden marginaal. ${ }^{73}$ Illustratief is de eerste monografie

lokaal verzet en oproer... op.cit., p. 97-101 en 110-111; HOUBEN B., Violence and political culture in Brabant. The Antwerp craft guilds' opposition against the central authorities in 1659, in DE SCHEPPER H., VERMEIR R. (red.), Hoge rechtspraak in de oude Nederlanden, Maastricht, 2006, p. 23-49.

72. Daardoor lijkt het misschien dat het neerslaan van de opstand in 1717-1718 uitermate hardvochtig was. Meerdere auteurs wijzen er echter op dat Anneessens en de andere gevangenen met relatief veel respect voor de gangbare procedureregels werden berecht. De handelingen van Maximiliaan Emmanuel van Beieren in 16991700 overschreden in veel grotere mate de rode lijn van wat wettelijk toelaatbaar was: GACHARD L.-P., Documents inédits... op.cit., vol. 1, lxxvii; GALESLOOT L., Procès... op.cit., vol. 1, p. xxvi, xxxii-xxxv en lxxii; BANNEUX P., Un épisode... op.cit., p. 179-183. We mogen deze handelingen niet afmeten aan onze eenentwintigsteeeuwse standaarden. Er bestond in de vroege achttiende eeuw simpelweg nog geen scheiding der machten, niet in de praktijk maar evenmin in de geesten.

73. Voor de voornaamste verhaallijnen in Anneessens'verheerlijking verwijs ik naar 


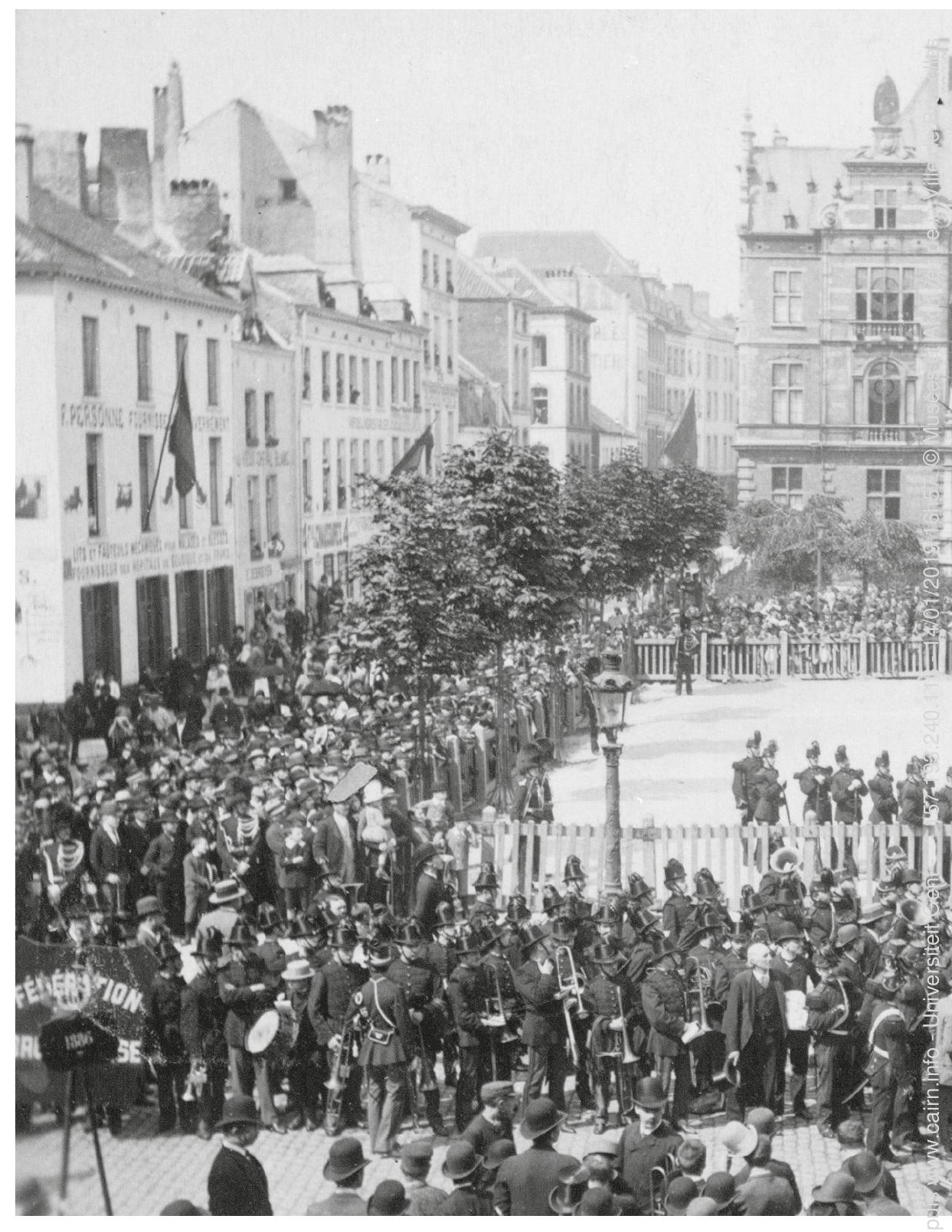

I11. 2: "Inhuldiging van het standbeeld ter ere van Frans Anneessens op de voormalige Oude Markt in Brussel (nu Anneessensplein) in 1889"

(A.V.B.| A.S.B., I.V., J-593). 


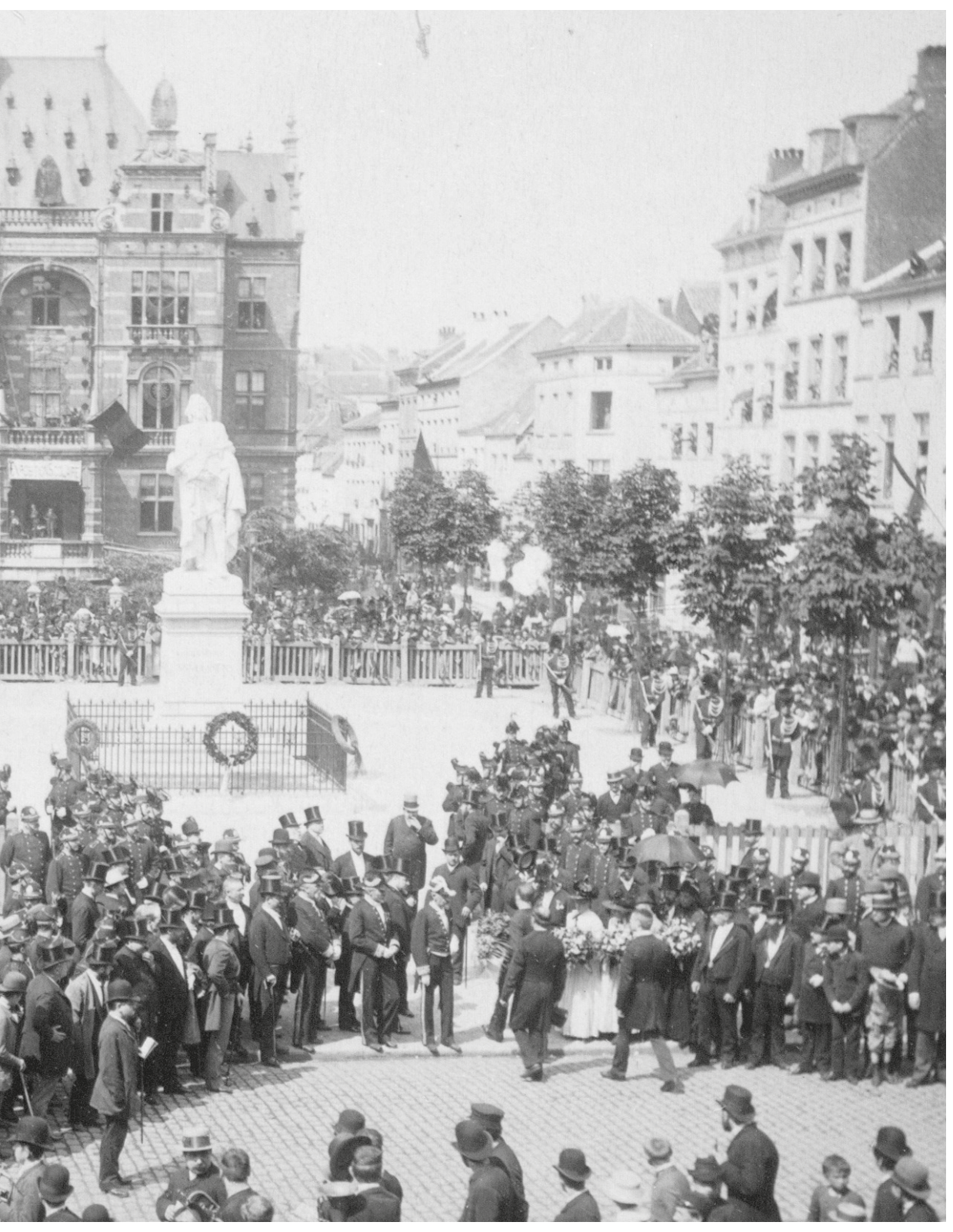


over de opstand door Pierre François Verhulst uit 1832. Zijns inziens waren de arrestaties illegaal en Priés ministerschap tiranniek en wraakzuchtig. ${ }^{74}$ De verhaallijnen van Anneessens' verheerlijking en Priés verkettering stonden in dienst van een groter doel: de legitimering van de jonge Belgische staat. Met een roemrijk verleden vol koene vrijheidsstrijders werden de onafhankelijkheidsstrijd in 1830 en Belgiës bestaansrecht onderbouwd en de nationale trots aangezwengeld. Op het podium van de grote Belgische helden kreeg Anneessens een plaatsje naast Ambiorix, Godfried van Bouillon, Jan Breydel, Pieter de Coninck en Jacob van Artevelde.

Pas in de twintigste eeuw en dankzij Henri Pirenne keerde het tij. Pirenne noemde de eisen van de dekens anachronistisch en gedoemd tot mislukken. ${ }^{75}$ In de plaats van het narratief van de vreemde overheersing kwam het even finalistische verhaal van de wasdom van de centrale staat die elk particularisme uitschakelde. Desalniettemin maakte Pirennes kentering gaandeweg een nuchterder benadering van de opstand mogelijk. Anneessens werd tot zijn ware proporties herleid en de zwarte legende rond Prié werd genuanceerd. Paule Banneux zette de toon met een studie die ook de context van het corporatieve verzet in beeld bracht. Voortaan werden de acties van de opstandelingen en van de overheid correcter afgewogen. De opstand werd een verhaal van (gefnuikte) ambities, keuzemogelijkheden en min of meer begrensde handelingsruimtes. De focus van de analyse verschoof van de twee hoofdpersonages naar de oorzaken van de opstand en de institutionele, fysieke en mentale kaders waarbinnen de betrokkenen ageerden.

het heldere overzicht in TASSIER, S., Idées et profils du XVIIIe siècle, Brussel, 1944, p. 27-31. De lezer vindt een synthese over de geschiedschrijving van de Brusselse opstand en het proces tegen Anneessens in VAN GELDER K., Markies van Prié... op.cit., p. 373-378. Voor een uitgebreid overzicht van de historiografie, in wetenschappelijke werken maar ook in handboeken voor het onderwijs: GOSSE M., Historiographie de François Anneessens, Brussel, onuitgegeven licentiaatsverhandeling ULB, 1993.

74. VERHULST P.F., Précis historique des troubles de Bruxelles en 1718; avec des détails inédits sur le procès et l'exécution d'Anneessens, Brussel, 1832.

75. PIRENNE H., Histoire de Belgique, des origines à nos jours, Brussel, 1973 (rijk geillustreerde heruitgave van het origineel uit 1921), vol. 3, p. 311-314. 
Overigens droegen in de negentiende eeuw niet enkel geschiedkundige werken de grootsheid van de nationale geschiedenis uit. Optochten, romantische schilderijen, historische romans, gedenkplaten en standbeelden herinnerden de Belgen aan hun eerbiedwaardige voorouders en de gevaren van despotische overheersers. Ook Anneessens viel die eer te beurt. Sinds 1851 is er in Brussel een Anneessensstraat en in 1889 werd op de voormalige Oude Markt een monument ter zijner ere ingehuldigd. Het plein met het monument werd herdoopt in het Anneessensplein; later ontleende ook de premetrohalte aan dat plein haar naam. ${ }^{76}$ De naamswijziging die Pascal Smet voorstelde, had de beste bedoelingen. De reactie van Zoubida Jellab toont echter dat de herinnering aan Anneessens nog steeds overeind blijft. Historisch onderzoek heeft inmiddels uitgewezen dat diens rol in de opstand lange tijd werd overschat - hij was slechts een van de vele actoren - en dat het reglement waartegen hij ten strijde trok, wel degelijk correct was uitgevaardigd. Anderzijds was elk reglement een middel om inspraak van onderuit te beknotten. Het onderzoek maakte ook duidelijk dat Anneessens een gildedeken was met kennis van de Brabantse geschiedenis, de privilegies van het hertogdom en de voorrechten van zijn ambacht. Vertrouwend op die kennis en met het nodige lef nam hij heldere politieke standpunten in. De moedige acties van de dekens en de waardige manier waarop Anneessens zich verdedigde, verdienen ons respect. Bovendien kan de naam 'Anneessens' ook symbool staan voor alle Brusselaars die voor het behoud van hun (voor)rechten geijverd hebben. Als een hommage aan hun burgerzin is het goed dat de premetrohalte niet van naam verandert. Een infobord over de historische figuur Anneessens, de opstand van 1717-1718 en de lange traditie van stedelijke opstandigheid in onze hoofdstad, zowel op het plein als in de premetrohalte, lijkt mij wenselijk. Het zou een mooi eerbetoon zijn aan al die veelal onbekende vrouwen en mannen die durfden contesteren.

76. GOSSE M., Historiographie... op.cit., p. 98-108. 